\title{
INVESTIGATIONS ON RECENT SEDIMENTS IN THE FISKENÆSSET REGION, SOUTHERN WEST GREENLAND
}

\author{
Dietrich Heling
}

During the regional geological mapping centred on the base camp Midgard (see Kalsbeek, this report) sampling of Recent sediments from lakes and fjords, as well as from the surface was undertaken by the author. The first month was spent sampling from five major fjords, Buksefjord, Sermilik, Grædefjord, Fiskenæsfjorden and Bjørnesund. In addition, the sediments in front of Frederikshåbs Isblink were inspected and sampled. During the second month samples were taken from some lakes within the drainage area of Fiskenæsfjorden and Grædefjord.

\section{Sampling method}

Submarine sampling was done by means of a Hydro-Bios grip sampler for clay-size sediments, and by a Van-Veen type sampler for sands. The samplers were run by manual operated winches on board the cutter Villiaumit as well as from a rubber boat and helicopter. The grip samples are good enough for compositional analyses. However, only meagre information about sedimentary structures (bedding, markings or casts) can be detected from them. A total of 122 samples, mostly muds, were taken from depths ranging between 0 and $275 \mathrm{~m}$.

\section{Nature and origin of the sediments}

The sediments sampled are derived almost entirely from the moraines brought down by glaciers. Erosion of soil on the ice-free part of the land accounts for only a negligible part of the total sediment since the soil cover is rather thin and tightly held by dense vegetation of mosses and scrub plants. Sand and clay are readily washed out of the moraines and carried downstream by water abundantly supplied by the glaciers. Frequently, the concentration of suspended matter in the water is very high so that even fine sand can be transported as suspension load due to the increased specific weight.

In most cases the greater portion of the bed load and some of the suspension load is trapped in a lake $1-5 \mathrm{~km}$ downstream of the glacier front. The initial depths of these glacially eroded lakes are assumed to have been around $100 \mathrm{~m}$. Today the sediment-water interface of the investigated lakes varies between 30 and $60 \mathrm{~m}$. Therefore a thickness of about $50 \mathrm{~m}$ of sediment, dominantly mud, can be considered to have accumulated in the lakes since the glacial retreat. Discharge and suspension load seem to vary considerably due to seasonal and temporary variations of temperature and precipitation making an estimate of the present sedimentation rate rather uncertain. Based on a rough approximation most of the 
lakes can be considered to become filled up by mud within 2000-6000 years. A considerable portion of the sediment is very finely dispersed being distributed over the whole area of a lake, even though the outlet may be close to the inlet thereby providing the possibility of short-cutting of the current. The homogeneous distribution of the mud throughout most of the lakes is revealed by the even level of the sediment surface as well as by the uniform milky colour over the entire area of the lakes.

All the mud samples show lamination probably caused by change in discharge. The muds are of light grey colour. Silty interstratifications are darker coloured.

After leaving the lake the water flows either directly to the head of a fjord, or it might enter another lake before it finally reaches sea level. Here the suspension load is still considerable although some of the mud initially washed out from the moraine has been trapped in the lakes upstream. For instance at Grædefjord the water from the glaciers distributed by Kûgssuaq carries sufficient mud to cover the downstream portion of Grædefjord with mud at least several tens of metres in thickness.

Where a glacier reaches sea level, for instance at Sermilik or Bjørnesund, no mud is trapped by upstream lakes but all the suspension load is poured directly into the fjord. In Sermilik mud sedimentation reaches a maximum among all the observed places. In this fjord the sediment surface is found at depths as shallow as $60 \mathrm{~m}$ about halfway between head and mouth of the fjord while at the bottom of this fjord more than $100 \mathrm{~m}$ of clay have been deposited.

Tidal undulations do not seem to influence the fine particle sedimentation in a broad fjord like Sermilik since the tides do not give rise to appreciable currents. But there are rather strong tidal currents in narrow passages as in the west fork of Fiskenæsfjorden downstream from Midgård where no clay is deposited. Flocculation may have some bearing on the clay sedimentation when the suspension comes in contact with the sea water, although large amounts of clay were found to be carried far into the ocean, for instance, off Frederikshäbs Isblink.

Generally, considerable sedimentation of the characteristic light grey clay is found only in those fjords having a drainage area including glaciers from the Inland Ice. The greater the movement rate of the glacier, the more moraine transported mud and the more glacial mud supplied. Isolated ice-caps or very slow moving 'inactive' glaciers, do not carry appreciable moraines and only very small amounts of mud are contributed by them. For this reason there is almost no clay in Buksefjord.

The shortest distance of transport is to be found at Frederikshåbs Isblink where the moraine is close to the sea shoreline. Since there is no fjord where the clay can settle a great part of it is swept out into the ocean where it is taken up by currents and transported over long distances. Samples taken as far as practicable off Frederikshåbs Isblink in about $40 \mathrm{~m}$ water depth were composed of silt rather than mud indicating that the mud had been taken farther out on the shelf. 


\section{Composition of the sediments}

According to X-ray diffractometer analysis the minus 2 micron fraction of the samples is composed of

$$
\begin{aligned}
& 30-70 \% \text { biotite } \\
& 10-20 \% \text { chlorite } \\
& 10-30 \% \text { hornblende } \\
& 10-30 \% \text { plagioclase } \\
& 5-20 \% \text { quartz }
\end{aligned}
$$

The X-ray patterns are marked by significantly high $\mathbf{I}_{(003)} / \mathbf{I}_{(\text {(M5) }}$ ratios of the biotite, indicating that the corresponding $\mathrm{Fe} / \mathrm{Mg}$ ratios in the octahedral layers of the mica are about 2:1.

The crystallinity index of the biotite from the muds, expressed by the width of the (001) peak at half height, is 2-3 times lower than that of the bedrock biotite (from gneisses and amphibolites) of similar grain size. This broadening of the (001) peak may reflect the beginning of the alteration of the mica to hydrobiotite.

The potassium content $\left(\mathrm{K}_{2} \mathrm{O}\right)$ of the minus 2 micron fraction of the muds, comprising an average $60 \%$ biotite, ranges from 3.4 to $3.6 \%$. Since there is no other component containing potassium in the clay fraction, all the $\mathrm{K}_{2} \mathrm{O}$ found in the analyses can be attributed to the biotite. The potassium content of the clay fraction corresponds to approx. $6 \% \mathrm{~K}_{2} \mathrm{O}$ related to the pure biotite from the muds. The $\mathrm{K}_{2} \mathrm{O}$ content of the bedrock biotite varies from 6.5 to $7.5 \%$. On the basis of these analyses the bedrock biotite seems to have suffered a loss in potassium of about $14 \%$ of its in situ content by erosion and transport by the melt waters. The leaching of potassium from the biotite is essentially supported by the mechanical grinding. Reduction of grain size corresponds with an increase in specific surface area, allowing the potassium ions exposed on the surface of the biotite flakes to diffuse into the water phase.

In accordance with the slight weathering effects on the mica, the cation-exchange-capacity of the mud biotite was found to vary between 27 to $45 \mathrm{meq} /$ $100 \mathrm{~g}$, indicating that some of the interlayer potassium had been exchanged by other ions, probably $\mathrm{Ca}$ and $\mathrm{Mg}$.

Laboratorium für Sedimentforschung, Mineralogisch-Petrographisches Institut, Der Universität Heidelberg, Berliner Strasse 19, D-69 Heidelberg 1 , West Germany. 